\author{
Ewa DomagaŁa-Zyśk
}

Katolicki Uniwersytet Lubelski Jana Pawła II

\title{
ZAPISYWANIE SYMULTANICZNE - ADEKWATNA FORMA WSPIERANIA EDUKACJI, PRACY ORAZ UDZIAŁU W ŻYCIU SPOŁECZNYM I KULTURALNYM OSÓB NIESŁYSZĄCYCH I SŁABOSŁYSZĄCYCH
}

Streszczenie: Artykuł przedstawia usługę zapisywania symultanicznego jako adekwatną formę wsparcia edukacji, pracy zawodowej oraz pełnego uczestnictwa w życiu społecznym i kulturalnym osób niesłyszących i słabosłyszących. Taki rodzaj pomocy znany jest w Europie Zachodniej od lat 80. XX wieku, jednak wciąż trwają dyskusje nad możliwym zakresem jej stosowania i finansowania, a także jak najbardziej efektywnymi metodami precyzyjnego zapisu mowy. W artykule omówiono różne typy zapisywania symultanicznego, przedstawiono zasady tworzenia zapisu symultanicznego oraz wskazano na zalety i trudności stosowania tej usługi.

Słowa kluczowe: niesłyszący, słabosłyszący, zapisywanie symultaniczne, velotypia, stenotypia, respeaking

\section{WPROWADZENIE}

Zapisywanie symultaniczne (speech-to-text-reporting) jest usługą polegającą na dosłownym (verbatim) i zrozumiałym zapisywaniu i wyświetlaniu na monitorze/ ekranie treści wypowiadanych, umożliwiając w ten sposób osobom z trudnościami w słyszeniu i rozpoznawaniu mowy udział w wykładach, rozmowach czy innych formach aktywności. Jest to jeden ze środków pozwalających takim osobom funkcjonować w życiu społecznym, co jest gwarantowane m.in. przez Konwencję o prawach osób niepełnosprawnych (2006) oraz inne dokumenty zapewniające osobom $\mathrm{z}$ niepełnosprawnościami równość $\mathrm{w}$ dostępie do edukacji, pracy i rozrywki. 
Omawianą usługę świadczą stenotypiści, palantypiści, velotypiści (w zależności od rodzaju używanej klawiatury), nazywani też tłumaczami pisemnymi (por. niem. Schriftdolmetscher, wł. interprete consecutif) czy też osobami zapisującymi mowę lub głos (speech reporters, voice writers, por. Nofftz 2014). Oczekiwana jakość przygotowywanego przez nich zapisu to $98 \%$ trafności, co jest możliwe przy szybkości pisania - w zależności od klawiatury - co najmniej 200-400 znaków na minutę.

W Polsce po raz pierwszy usługa zapisywania symultanicznego została wykorzystana w 2012 roku przez Polską Fundację Osób Słabosłyszących w czasie spotkania w sejmie RP oraz na Katolickim Uniwersytecie Lubelskim Jana Pawła II podczas konferencji naukowej Odpowiedzialność za edukację osób z uszkodzeniami słuchu (25-27 października 2012 roku w Lublinie)

Zapisywanie symultaniczne umożliwia osobom niesłyszącym i słabosłyszącym pełniejsze uczestnict wo w lekcjach, zajęciach, konferencjach czy spotkaniach. Poznając na bieżąco przekazywane treści, mogą zadawać pytania i komentować wypowiedzi na równi ze słyszącymi uczestnikami narad, wykładów czy innych spotkań. Zakres korzystania z tej usługi w 25 krajach zbadała Birgit Nofftz (2014). Z zebranych danych wynika, że osoby niesłyszące i słabosłyszące najczęściej wykorzystują usługę zapisywania symultanicznego w pracy zawodowej, w czasie konferencji i załatwiania spraw urzędowych, w dalszej kolejności w czasie szkoleń, w sądzie, kościołach, w szpitalu i u lekarza, na uniwersytetach i w szkołach (por. wykres 1).

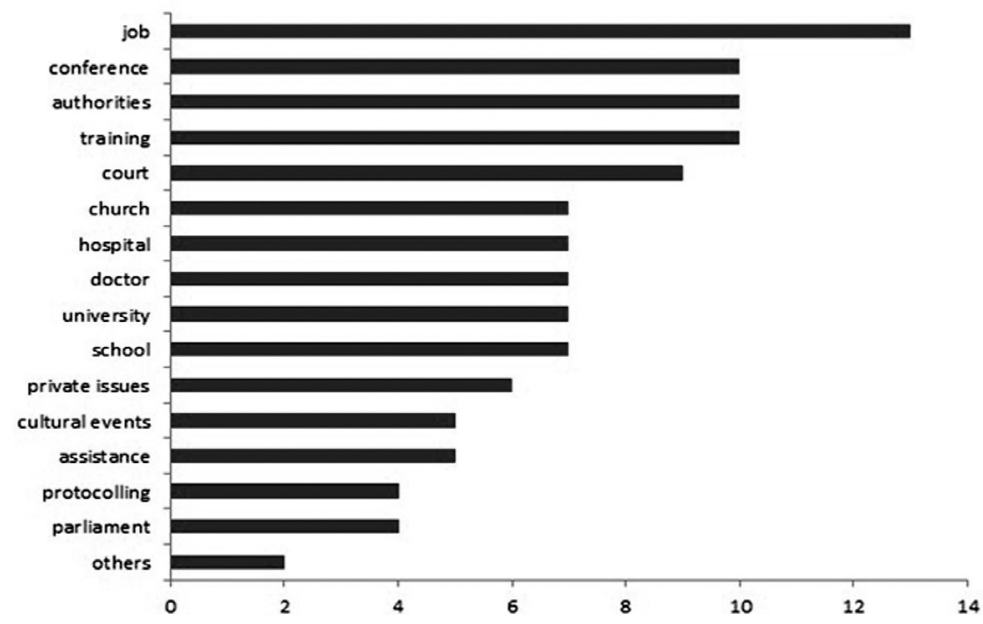

Wykres 1. Sytuacje, w których osoby niesłyszące i słabosłyszące wykorzystują zapisywanie symultaniczne (za: Nofftz 2014)

Celem artykułu jest dokonanie charakterystyki usługi zapisywania symultanicznego oraz wskazanie zasad, form i możliwości jej wykorzystania w edukacji 
i rehabilitacji osób niesłyszących i słabosłyszących. Zapisywanie symultaniczne jest usługą oferowaną studentom Katolickiego Uniwersytetu Lubelskiego Jana Pawła II, gdzie pionierskie działania w tym zakresie pod kierunkiem autorki rozpoczął w roku akademickim 2014/2015 Grzegorz Potocki, zdobywca I miejsca na mistrzostwach Polski w pisaniu na klawiaturze w 2013 roku i II miejsca w 2014 roku - szybkość pisania laureata to 514 znaków na minutę. Usługa zapisywania symultanicznego cieszy się coraz większym zainteresowaniem niesłyszących i słabosłyszących studentów KUL-u także z tego względu, że zauważają oni, jakie usługi oferowane są na uczelniach zagranicznych, i odczuwają potrzebę korzystania z nich w Polsce, co wiąże się z koniecznością uporządkowania dotychczasowej wiedzy i doświadczeń w tym zakresie.

\section{OGÓLNE INFORMACJE O USŁUDZE ZAPISYWANIA SYMULTANICZNEGO}

Początków usługi zapisywania symultanicznego należy szukać w usługach stenografów i stenotypistów pracujących w sądach i przygotowujących szczegółowe protokoły z rozpraw. Umiejętności posiadane przez te osoby zaczęto w latach 80 . postrzegać jako użyteczne także w środowisku osób niesłyszących i słabosłyszących i wykorzystywać zapisywanie symultaniczne także na uczelniach wyższych i w szkołach średnich oraz w czasie spotkań i konferencji. Specjalistyczna praca stenotypistów wspierana jest coraz nowszymi urządzeniami elektronicznymi, takimi jak specjalne klawiatury, oraz programami komputerowymi, które umożliwiają uzyskiwanie efektu zapisania całej sylaby lub słowa przez jedno uderzenie w klawiaturę.

W USA usługa zapisywania symultanicznego znana jest jako Computer Assisted Notetaking (CAN, wspierane komputerowo przygotowywanie notatek), Computer Assisted Real-Time Translation (CART, tłumaczenie w czasie rzeczywistym wspierane komputerowo), Communication Access Real-Time Translation (CART, komunikacja dostępna w formie tłumaczenia w czasie rzeczywistym) lub też C-print (communication in print, komunikacja w piśmie). Dla tej ostatniej formy usługi używa się także określenia captioning - przygotowywanie napisów (por. np. Kushalnagar, Lasecki, Bigham 2014), chociaż zasadniczo obejmuje ona przygotowywanie zapisu tekstowego wypowiedzi z filmów, przedstawień i innych prezentacji audiowizualnych. Przygotowywanie napisów jako formy wsparcia edukacji i rehabilitacji osób niesłyszących i słabosłyszących omówiono w innym artykule (Domagała-Zysk 2016, 2017), dlatego w niniejszej pracy przedmiotem analizy będzie jedynie usługa zapisywania symultanicznego wypowiedzi bezpośrednich, a nie tych w filmach czy innych formach artystycznych. 
Współcześnie wyróżniamy pięć systemów zapisywania symultanicznego:

1. Stenografia

2. Zapisywanie przy użyciu klawiatury komputerowej

3. Zapisywanie przy użyciu klawiatury velotypowej

4. Stenotypia

5. Respeaking

Stenografia to metoda szybkiego i ścisłego zapisu ręcznego. W praktyce oznacza to, że osoba zapisująca stosuje specjalne znaki w celu oddania liter czy słów oraz skróty pozwalające na bieżący zapis rozmów, przemówień, dyskusji, czynności sądowych czy urzędowych (Stenografia: http://www.stenografia.pl). Zapis stenograficzny może też być wyświetlany przy pomocy projektora i w ten sposób umożliwiać udział w ważnych rozmowach, wykładach czy spotkaniach osobom niesłyszącym i słabosłyszącym. Prędkość zapisu wynosi ok. 30 słów na minutę, co oznacza, że zapisane może być, co 5-6 słowo z tych wypowiadanych. Zapis stenograficzny przypomina zatem bardziej notatkę niż bieżący zapis mowy, jednak nadal może być wykorzystywany w sytuacji, gdy nie ma innych możliwości, w pomieszczeniach, gdzie niemożliwe jest korzystanie z elektronicznego zapisywania symultanicznego, np. w kawiarni, muzeum czy na łonie natury.

Zapisywanie przy użyciu tradycyjnej klawiatury komputerowej QWERTY daje znacznie większe możliwości precyzyjnego i szybkiego zapisu niż klasyczna stenografia. Klawiatury można wykorzystywać do zapisu wypowiedzi w wielu językach, istnieją także różne modele przeznaczone do wielogodzinnej pracy, np. klawiatury o mniejszej wysokości klawiszy, bardziej ergonomicznym kształcie itp. Można również używać skrótów i programów komputerowych, które zwiększają szybkość pisania. Wykorzystanie klawiatury tradycyjnej pozwala zazwyczaj na zapisanie 200 znaków na minutę, choć biegli użytkownicy potrafią pisać z prędkością 300, a nawet 400 znaków na minutę. Klawiatura velotypowa pozwala natomiast na zapisywanie słów sylabami - po naciśnięciu danego klawisza wyświetla się cały wyraz, przy czym jego początkowa część powstaje przez uderzenie lewej ręki, a końcowa sylaba zapisywana jest ręką prawą. W celu zwiększenia szybkości zapisu stosuje się także skróty. Praca na klawiaturze velotypowej umożliwia zapisywanie mowy z szybkością ok. 400 znaków na minutę.

Kolejna forma zapisywania symultanicznego to stenotypia, nazywana także stenografią maszynową. Jest to sztuka szybkiego zapisywania wypowiedzi z wykorzystaniem klawiatury (Stenografia: http://www.stenografia.pl). Stenotypiści, aby zdążyć z zapisem mowy, posługują się skrótami, korzystają także z tzw. zapisu akordowego, czyli wciskając kilka klawiszy jednocześnie, uzyskują zapis całego słowa lub nawet frazy. 
Coraz bardziej popularną i dostępną formą zapisywania symultanicznego jest respeaking, czyli zapisywanie symultaniczne z wykorzystaniem urządzeń automatycznego rozpoznawania głosu (Automatic Speech Recognition, ASR). Dzięki tej technice możliwe jest przygotowywanie zapisu mowy na podstawie jej rozpoznawania przez urządzenie. Tak przygotowany zapis nie jest jednak pozbawiony błędów i nieścisłości wynikających np. z zapisania błędnie homofonu danego słowa lub wyrażenia (np. „right” zamiast „write”, czy „pole cenię” zamiast „polecenie”). $\mathrm{Z}$ tego względu konieczne jest przed wyświetleniem tekstu na monitorze czy ekranie dokonanie edycji przez człowieka.

\section{TŁUMACZE CZY STENOPTYPIŚCI?}

Część środowisk wspierających osoby z uszkodzeniami słuchu uważa, że rola osoby zapisującej tekst symultanicznie na potrzeby osób niesłyszących i słabosłyszących jest tak specyficzna, że powinni oni być nazywani tłumaczami, analogicznie do tłumaczy symultanicznych wykonujących podobną pracę oraz tłumaczy języka migowego czy też tłumaczy ustnych (oral interpreters) powtarzających to, co zostało powiedziane ze zbyt dużej odległości lub niewyraźnie. Zapisywanie symultaniczne nie jest bowiem prostym zapisem tego, co jest wypowiadane, ale wymaga podejmowania decyzji co do koniecznych zmian, które sprawią, że tekst nie tylko będzie przeczytany, ale także zrozumiany przez odbiorcę. Wymaga to znajomości klienta, szerokiej wiedzy ogólnej, zamiany słów na bardziej zrozumiałe itp.

Najczęściej jednak nazwy określające osoby wykonujące usługę zapisywania symultanicznego to stenotypista lub velotypista. Praca ta jest zajęciem wysoce specjalistycznym i wymaga wielu miesięcy lub nawet lat specjalnego szkolenia, w czasie którego adepci zapoznają się z możliwościami używanego sprzętu: klawiaturą tradycyjną QWERTY, palantypową (fotografia 1) czy też welotypową (fotografia 2) i oprogramowania (np. dla klawiatur stenotypowych są to programy Eclipse, Case CATalyst i Digital CAT), a następnie ćwiczą szybkość i dokładność zapisu. Dobrzy specjaliści osiągają biegłość po ok. 2-4 latach treningu. Ważnym elementem szkoleń jest także nabywanie wiedzy i kompetencji w zakresie pracy z osobami niesłyszącymi i słabosłyszącymi (deafness awareness) tak, aby podejmować najbardziej adekwatne decyzje (np. dotyczące edycji zapisywanego tekstu). Konieczne jest też nabycie kompetencji w zakresie różnych metod komunikowania się z osobami z uszkodzeniami słuchu, aby móc precyzyjnie ustalić oczekiwania i zasady oraz możliwości ich realizacji.

Stenotypiści, palantypiści czy velotypiści zazwyczaj prowadzą własną działalność gospodarczą, wykonując poszczególne zlecenia, a w celu podnoszenia jakości pracy i zwiększania dostępności usług zrzeszają się w krajowych lub regionalnych 
stowarzyszeniach (np. Association of Speech-to-Text Reporters, http://avsttr.org. uk). Stenotypiści na ogół pracują samodzielnie, ale zaleca się, żeby przy zleceniach dłuższych niż 2 godziny pracowali w parach i mogli - podobnie jak inni tłumacze - zmieniać się co jakiś czas, dzięki czemu będą bardziej efektywni.

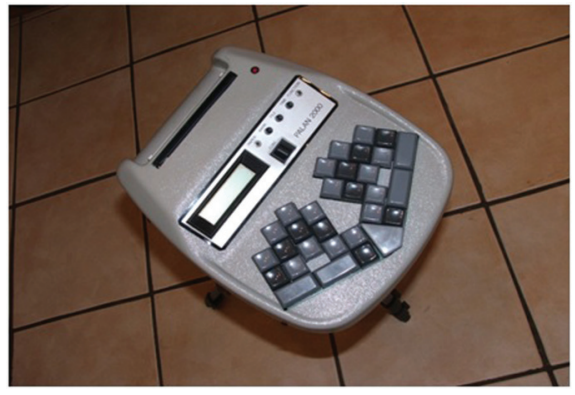

Fotografia 1. Klawiatura palantypowa

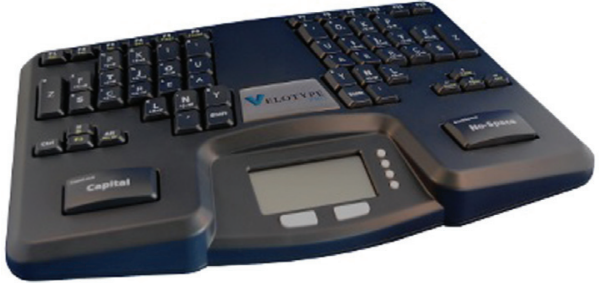

Fotografia 2. Klawiatura velotypowa

Usługa zapisywania symultanicznego rozwinęła się zwłaszcza w takich krajach, jak Szwecja, Holandia i Wielka Brytania. W Szwecji pierwsi stenotypiści pracowali z osobami niesłyszącymi i słabosłyszącymi już od roku 1980 (Nofftz 2014), a usługi opłacane są z funduszu państwowego w ramach pokrywania kosztów dostępu do informacji w edukacji, pracy zawodowej, w sądach oraz w czasie szkoleń. Klienci sami płacą natomiast za zapisywanie symultanicznew innych sytuacjach (np. w czasie wizyt u lekarza, nabożeństw, konferencji i innych spotkań). W Holandii pierwsi velotypiści rozpoczęli świadczenie usług osobom z uszkodzeniami słuchu już w roku 1984 (Nofftz 2014), a od roku 2002 odbywają się w tym kraju regularne dwuletnie kursy na uczelni Hogeschool van Utrecht (HBO) przygotowujące do pracy w tym zawodzie. Osoby niesłyszące i słabosłyszące w ramach usług opłacanych $\mathrm{z}$ funduszy publicznych mają prawo do zapisywania symultanicznego w czasie $15 \%$ godzin pracy zawodowej oraz do $100 \%$ godzin zajęć w szkole i na uczelni do 30. roku życia. Usługa obejmuje także 30 godzin rocznie zapisywania symultanicznego w czasie spotkań prywatnych (Nofftz 2014). Wielka Brytania oferuje tę formę usługi dla osób niesłyszących i słabosłyszących od lat 90.; stosowane są w tym kraju 
głównie klawiatury palantypowe. Szkolenie obejmuje naukę szybkiego zapisywania, a następnie po nabyciu biegłości specjalne kursy przygotowujące do pracy z osobami niesłyszącymi i słabosłyszacymi. Usługodawcy traktowani są jako specjaliści w zakresie komunikacji i powinni być zarejestrowani w specjalnym rejestrze (The National Register of Communication Professionals for Deaf and Deafblind People). Usługa dostępna jest przede wszystkim dla osób uczących się na uczelniach wyższych w ramach specjalnych funduszy dla studentów z niepełnosprawnościami.

\section{ZASADY I FORMY ZAPISYWANIA SYMULTANICZNEGO}

Jak już stwierdzono powyżej, zapisywanie symultaniczne to nie tylko precyzyjne przedstawienie za pomocą pisma tego, co jest mówione. Wyświetlany tekst powinien być nie tylko jak najbardziej dosłownym, ale także zrozumiałym dla odbiorcy zapisem mowy. Czasem ze względu na zbyt szybkie tempo mówienia osoba zapisująca musi dokonywać skrótów i przekształceń wypowiedzi. W innych sytuacjach biorąc pod uwagę odbiorcę i jego zasób słownictwa - osoba zapisująca może uznać, że potrzebne jest dokonanie edycji usłyszanego wywodu, aby był on zrozumiały. To się może zdarzyć się np. na wykładzie czy trudnej lekcji albo np. w czasie zapisywania symultanicznego na wizycie u lekarza. Tak jak wspomniano wcześniej, osoba zapisująca powinna zatem znać potrzeby klienta, dla którego pracuje i starać się na nie adekwatnie odpowiedzieć, czyli przygotować tekst jak najbardziej dosłowny, ale jednocześnie zrozumiały.

Zapis wyświetlany użytkownikowi musi zawierać nie tylko wypowiedziane słowa, ale także pewne określenia ułatwiające zrozumienie zapisu. Przed rozpoczęciem zapisu wypowiedzi kolejnego mówcy powinien zatem pojawić się napis „NOWA OSOBA: Chciałabym dodać, że...”, a jeśli znane są jej dane - imię i/lub nazwisko, np. „PROFESOR NOWAK: Teraz zajmiemy się...”. Zapis powinien także zawierać o informacje o różnych dźwiękach słyszanych w miejscu, w którym dobywa się spotkanie; zazwyczaj umieszcza się je w nawiasach, np. \{śmiech\}, \{pojedyncze brawa $\mathrm{z}$ tylu sali\}, \{gwizdanie po prawej stronie\}. Osoba zapisująca powinna przekazywać jak najdokładniej także inne cech mowy, np. słowa charakterystyczne dla danego mówcy, choć nieużywane powszechnie, wyrażenia regionalne czy dialektalne. Ważne jest także zaznaczanie pewnych cech związanych z płynnością wypowiedzi lub jej brakiem, np. „hmmmm”, „yyyy”, „to jest...” „ale...”, czy też momenty ciszy, ponieważ jeśli nic nie pojawia się na ekranie osoba niesłysząca nie wie, czy na sali panuje cisza i nikt nic nie mówi, czy przerwa wynika np. z konieczności chwilowego odpoczynku osoby zapisującej.

Po zakończeniu zapisywania symultanicznego wypowiedzi osoba niesłysząca/ słabosłysząca może otrzymać zapis w wersji elektronicznej lub drukowanej. Może 
on być zapisem „na żywo” lub też zapisem po dokonaniu edycji, a nawet autoryzacji. W każdym przypadku wymaga to jednak zgody osób biorących udział w spotkaniu/ wykładzie/lekcji na utrwalenie wypowiedzi w taki właśnie sposób.

Posiadanie takich zapisków czy dokładnych (verbatim) notatek pozwala na wielokrotne wracanie do utrwalonych w ten sposób treści, uczenie się czy też lepsze zrozumienie. Należy jednak pamiętać, że taki stenotypowy zapis nie zastępuje dobrze przygotowanej notatki z zajęć, jest bowiem zbyt długi i chaotyczny, chociaż zawiera dokładne wypowiedzi prowadzącego (por. np. Lang 2002). Zaletą notatki jest uporządkowanie jej treści oraz mniejsza objętość, co ułatwia szybkie z niej korzystanie. Stenotypowy zapis wielu wykładów czy lekcji zawiera często informacje nieustrukturyzowane, a to, co jest zaletą przy śledzeniu wypowiedzi na ekranie momencie jej wygłaszania, czyli zapis sygnałów niewerbalnych, braku płynności mowy itp., w znaczący sposób utrudnia późniejsze korzystanie z treści zapisanych symultanicznie.

Inną wadą tego sposobu wsparcia jest to, że w czasie zajęć student niesłyszący/ słabosłyszący musi być cały czas skoncentrowany na patrzeniu na ekran czy monitor, przez co traci możliwość obserwowania wykładowcy, jego mimiki i ekspresji ciała i może nie dostrzec pewnych informacji przekazanych właśnie w taki sposób (np. ironii wyrażonej przez skrzywienie ust itp.).

Rozwiązaniem powyższych problemów jest korzystanie równolegle z innej formy wsparcia - tworzenia specjalistycznych notatek (notetaking). Mogą one być przygotowywane ręcznie (manual notetaking) lub elektronicznie (electronic notetaking). Zawierają one dokładny zapis treści mówionych, jednak osoba sporządzająca notatkę świadomie dokonuje jej edycji i skraca usłyszane treści tak, aby tekst był zrozumiały, ustrukturyzowany i w jak największym stopniu ułatwiał uczenie się. W takich notatkach pojawia się nie tylko tekst, ale także rysunki, schematy czy podkreślenia - zarówno sugerowane przez wykładowcę, jak i zaproponowane przez osobę robiącą notatkę. Korzystanie z takiej pomocy umożliwia osobom niesłyszącym i słabosłyszącym uczestniczenie w wykładzie dzięki odczytywaniu mowy z ust lub śledzeniu symultanicznego zapisu wypowiedzi na ekranie bez konieczności jednoczesnego przygotowywania notatki. Z kolei po zakończeniu zajęć mogą oni nie tylko polegać na swojej pamięci, ale otrzymują tekst, na podstawie którego mogą utrwalać i rozszerzać wiedzę. Należy jednak pamiętać, że nawet najlepsza notatka nie rozwiąże problemu rozumienia treści (McCrea, Turner 2007), więc zazwyczaj zapisywaniu symultanicznemu towarzyszy zarówno przygotowywanie notatek, jak i tutoring indywidualny. 


\section{PODSUMOWANIE}

Dzięki zapisywaniu stymultanicznemu osoby z uszkodzeniami słuchu mają możliwość bezpośredniego dostępu do treści przekazywanych za pomocą mowy zarówno w języku ojczystym, jak i w językach obcych. Jest to usługa szczególnie pożądana przez studentów i uczniów szkół średnich, ponieważ dzięki niej niesłyszący czy słabosłyszący pokonuje barierę fizycznej dostępności mowy i w większym stopniu może kontrolować proces uczenia się. Zapisywanie symultaniczne pozwala również na aktywny udział w spotkaniach zawodowych, załatwianie spraw urzędowych, a także jest pomocne np. w czasie wizyty u lekarza, w banku czy też zakupu nowego urządzenia. Z usługi tego rodzaju korzystają osoby niesłyszące i słabosłyszące w różnych krajach, dlatego konieczne jest zwiększenie dostępności takiej oferty również w Polsce.

\section{LITERATURA}

Domagała-Zyśk E., 2013, Wielojęzyczni. Studenci niesłyszący i słabosłyszący w procesie uczenia się nauczania języków obcych. Lublin, Wydawnictwo KUL, 420.

Domagała-Zyśk E., 2016, Napisy jako forma wspierania edukacji i funkcjonowania społecznego osób niesłyszących i słabosłyszacych. W: W. Otrębski, K. Maryniarczyk (red.), Przepis na rehabilitację. Dzieci i młodzież z niepełnosprawnościa. Gdańsk, Harmonia Universalis, 41-53.

Domagała-Zyśk E., 2017, Notatki jako forma wsparcia edukacji studentów i uczniów niesłyszacych i słabosłyszących. „Niepełnosprawność”, II/23, 53-66.

Kushalnagar R.S., Lasecki W.S., Bigha J.P., 2014, Accessibility evaluation of classroom captions. "ACM Trans. Access. Comput", 5, 3, DOI: http://dx.doi.org/10.1145/ 2543578.

Lang H.G., 2002, Higher education for deaf students: Research priorities in the new millennium. "Journal of Deaf Studies and Deaf Education", 7/4, 267-280.

McCrea K., Turner P., 2007, Can you put that in writing? W: L. Barnes, F. Harrington, J. Williams, M. Atherton (red.), Deaf Students in Higher Education: Current research and practice. Coleford, Gloucestershire, Douglas McLean Publishing, 102-118.

Nofftz B., 2014, Written Interpreting in Individual Countries, opublikowano: http:// www.uni-saarland.de/en/campus/faculties/professorial-staff/philosophische-fakultaet-ii/angewandte-sprachwissenschaft-uebersetzen-dolmetschen/professorial-staff-dept-46-applied-linguistics-and-translationinterpreting/atrc/aktuelles. html [dostęp: 16.02.2016]. 
Słów kilka o pracach nad stenotypia polską, opublikowano: http://www.stenografia.pl [dostęp: 12.02.2016].

Standard of Service - Sept 08, opublikowano: http://avsttr.org.uk/ [dostęp: 12.02.2016]. Stenografia, opublikowano: http://www.stenografia.pl [dostęp: 12.02.2016].

\author{
SPEECH-TO-TEXT REPORTING - AN APPROPRIATE FORM OF SUPPORT \\ FOR EDUCATION, WORK AND PARTICIPATION IN SOCIAL AND \\ CULTURAL LIFE OF THE DEAF AND HARD OF HEARING PERSONS
}

\begin{abstract}
This article presents speech-to-text reporting as an adequate form of support for education, work and full participation in social and cultural life of the deaf and hard of hearing. This form of support is known in Western Europe since the 80s of the twentieth century. However, there are a lot of discussions nowadays as for its scope and financing as well as the most effective forms of precise speech recording. The article discusses different types of speechto-text reporting, shows the rules for creating the recordings and points out the advantages and difficulties of using this service.
\end{abstract}

Keywords: deaf, hard of hearing, speech-to-text reporting, velotype, stenography, re-speaking 